\title{
Dominant Regulatory Factor of Shoreline Erosion Process: The Case of Western Coastal Sector in Sri Lanka
}

\author{
Amarasinghe A. G. \\ Head, Department of Geography, \\ Faculty of Social Sciences, University of Kelaniya, Sri Lanka, \\ DOI: 10.29322/IJSRP.10.12.2020.p10813 \\ http://dx.doi.org/10.29322/IJSRP.10.12.2020.p10813
}

\begin{abstract}
Shoreline erosion process regulate by several factors which derive from interior of the earth, atmosphere, hydrosphere, lithosphere and biosphere. Gravitational force of the moon is also a considerable factor that determine the shoreline erosion rate. Thus, natural forces, process and dynamism belong to endogenic, exogenic, extraterrestrial along with anthropogenic origin control the recession and accretion level of the shoreline and denudation process of the coast. Literature and ground truth data reveals that shoreline erosion cycle is complex process which influence all kinds of dynamism, actions and processes belong to geo-system. The clear picture of this is still mystery. However, it can be conclude when referring geological and geomorphological history of Sri Lanka, the natural forces and process that regulate the shoreline erosion in Western coast (study area) are constant. The current study surfaces the fact that the anthropogenic (Human activities) influence with slow rise of sea level have become leading factors that determine the coastal erosion process in particularly in the West coast of Sri Lanka. Reduction of beach sediment supply and constructing hard structures to protect properties from shoreline erosion along beaches from where sediment comes have become dominant factors that regulate the erosion rate in the study area.
\end{abstract}

Index Terms- Coast erosion process, Regulatory factors of coastal landforms, Denudation of shoreline,

\section{INTRODUCTION}

Shoreline erosion can be identified as the constant, relentless and visible land mass denudation process that cause to wearing away the surface of the earth (Amarasinghe, 2004). Waves caused by wind are the main erosion agent of the formation of coastal landforms. When the fetch is long enough to developed powerful waves and a major global wind path cross the coast line, shoreline erosion process is more dynamic and perpetual. South West and Western coastal sectors of Sri Lanka faces for huge Indian Ocean fetch and South Asian Monsoon wind path. Temporal and special span of appearing and disappearing coastal landforms of such coasts are very short. Livelihoods and lifestyles of these coast collapse suddenly. This has surfaced as a disaster. Such kind of disastrous situation hit the Western coastal sector in Sri Lanka from recent past (CCD, 1997). It is general truth that fetch does not change suddenly. Wind systems that effect to generate waves can be changed gradually or take some time to witness significant change. Without changing these two factors, many coastal zones of Sri Lanka which had been beach or land area around thousand year history wearing away within few days or few weeks. This means other factors than fetch and wind system influence as dominant factor/s to regulate shoreline erosion process. Main and broad objective of this study is to engage to investigate on this matter. 
Sri Lanka is a small island of 65610 sq.km land area. Yet the population density is six or seven times higher than many developed countries. Population density, urban land area, industrialized area and other land areas that contribute national GDP are significantly higher in the coastal zone in Sri Lanka than other parts of the country. Approximately 1620km long coastline including shoreline of bays and inlets but excluding lagoons is belong to this country (CCCRMD, 2018). Such valuable land is eroding rapidly creating vast array of socio-economic, environmental, cultural and political issues. According to the calculation of CCD in 1986 and 2006 the intensity of shoreline erosion vary from $0.0-3.0 \mathrm{~m} / \mathrm{yr}$ (Amarasinghe, 2020). This figure will increase up to $7 \mathrm{~m} / \mathrm{yr}$ in 2050 and $22 \mathrm{~m} / \mathrm{yr}$ in 2100 (Bakker, 2018). Ground reality of the disaster of coastal erosion is more serious than literature reported. At the same time, spending enormous amount of money to build hard structures to control shoreline erosion have become a starting point to accelerate erosion in long stood wide beaches in adjacent coastal sectors. Therefore, main objective of this paper set as to find what the dominant factors of shoreline erosion are. Result of this study may help to understand the main cause that influence to accelerate erosion particularly in West coast of Sri Lanka.

\section{METHOD AND MATERIALS}

Existing knowledge on the shoreline denudation process and related physical process of the four geospheres of the earth was reviewing with the help of available digital and printed literature. Literature survey was the main secondary data collection method applied in this study. Analyzing satellite images and questionnaire survey were applied to collect relevant primary data. Conceptual data analyze method and basic cartographic techniques were employed to analyze raw data. Flowcharts, maps images and tables were used as results presentation techniques in this study.

\section{Study Area: West Coastal Sector of Sri Lanka}

West coast as designated by the then Coast Conservation Department of Sri Lanka in 1986 comprised with shorelines belong to two administrative districts of Sri Lanka named Gampha and Puttlam (Fig. 01). Length of West coast is 340kms and $21 \%$ of the total length of coastline belong to Sri Lanka (CCD, 1986).

Figure- 01 


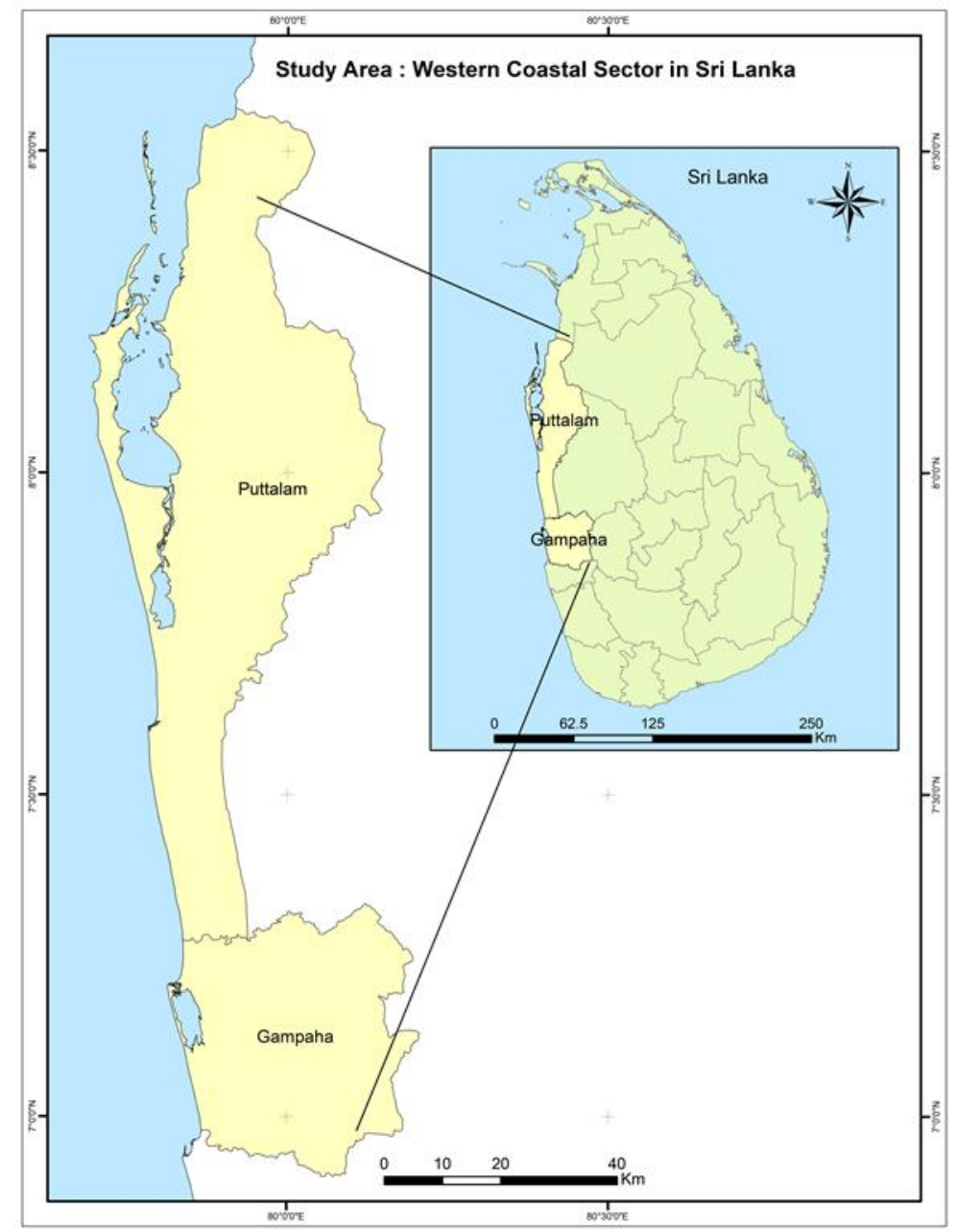

According to the CCD (1986), net erosion of this coast varies from $0.2-1.0 \mathrm{~m}$ per year. This figure is higher rate when comparing to national figure, $0.2-0.35 \mathrm{~m} / \mathrm{yr}$ as mentioned in the same report in 1986. Yet, the erosion rate is higher than this figure when comparing with the erosion rate for the period of 2015-2020.

West coast is made up with old beaches and sand dunes belong to Holocene and Pleistocene periods of Cainozoic geological era (Cooray, P.G. 1983). That means the age of this coastal sector is just 0.01 to 2.0 million years. Raised beaches and dune deposits, older alluvium, laterite, nodular ironstones and submarine canyons cuts belong to Pleistocene periods can be seen in coastal starch belong to Puttalam district. Drowning continental self during the post glacial sea level rise, younger raised beaches and dune deposits, beach rocks, recent alluvium and lagoons belong to Holocene period can be seen within the coastline belong to Gampha district (Swan, B. 1983).

West coast is comprised with wide beaches and wide continental self. Beach profile consist with low gradient slope compared to South Western coastal sector of Sri Lanka. Therefore, 1 waves crest are almost to shoreline alignment. Density of population, urban area, industrial areas are also low when comparing to South and South Western coastal sectors of Sri Lanka (CCCRMD, 2018).

\section{Discussion and Results}


It is a general truth that land mass denudation process leads to gradation the earth surface. Gradation is accomplished by degradation and aggradation process (Spencer, E.W.1983). These processes can be seen in the shore in a single occasion at two different places or in one place at two different times. Weathering, erosion, transportation and deposition of rocks materials are the main influencing four geomorphic processes that determine the nature of the shoreline degradation and aggradation intensity (Leopold, Wolmand and Miller, 1964). Weathering of bed rocks, erosion of weathered rocks, dunes and beach, transportation of eroded sediments by the near shore wave action and deposition sediment load are the main results associated with the geomorphic process related to land mass denudation process of the shore (Huggett, 2011). This reveals that number factors that determine the actions, reactions, dynamism, interactions and infractions related to "geomorphic cycle" involve as regulating factors of the shoreline erosion process (Haggett, 1979). Knowledge of these factors can be traced by reviewing literary works relating to the subject of Geomorphology. For instances, concepts of Davisian Cycle of Erosion, Marine Dissection Theory of Sir Charles Lyell (1846), Cycle of Marine Erosion of D.W. Johnson (1919) and classical works of Aristotle (384-322 B.C.) and Leanodo Da Vinci (1452 -1519 B.C.) can be given( Amarasinghe, 2004). Reviewing and analyze these literary works and incorporate ground truth realities would pave the way to identify the responsible factor that regulate the shoreline erosion process. This infusion would help to identify the most influential and key factor/s that regulate the shoreline erosion process of the Western Coastal Sector of Sri Lanka. Findings of this study may help immensely to solve the array of problems associated with shoreline erosion process in the Island of Sri Lanka as well as other countries.

As mentioned above, shoreline erosion is a complex geomorphic process which involves number of forces, processes and formations of relief features of the coast (Huggett, 2011). Formation of coastal landforms are the product of different types of chemical and physical actions, reactions, interactions and infractions relate with "geomorphic cycle of shoreline erosion" (Haggett, 1979). All these process and dynamism relate directly or indirectly with the forces and processes of atmosphere, hydrosphere, lithosphere and biosphere. This shows that shoreline erosion process is a natural process which consists with number of regulatory factors that control the forces, processes and dynamism of the shoreline erosion derived from whole geo-system (King, 1972; Swan, 1965).

Almost all anthropogenic activities of coastal zone as well as interior of river basins which supply sediments to coast influence to alter shoreline erosion process (Hinrichsen, 1994). Impacts of all these factors may appear directly, indirectly or reciprocally. Magnitude and the level of intensity may be vary from temporally and spatially. Recurrence intervals of some of these factors is seasonal, annual or few years. Therefore, when considering the appearing and activation period of time, regulatory factors of shoreline erosion can also be categorized into two as short term and long term factors (Amarasinghe, 2001).

\section{Regulatory Factor of the Shoreline Erosion Process and Their Interactions}

Shoreline undergoes relentless attack by the sea waves. Waves supply the required force to activate geomorphic process of the shoreline to wearing away shoreline and to produce various types of coastal landforms. Geomorphic process of the coast is driven by three types of forces; Endogenic, exogenic and human activities (Fig. 02). Endogenic or geological forces can be divided into two as eustatic and isostatic forces. The isostatic equilibrium influence to uplift or submerge the near shore sea floor level resulting eustatic sea level change. Forces associated with the exogenic are divided into two as atmospheric and extraterrestrial forces. Atmosphere influences to change sea level and to modify the wave climate of the sea. Wave climate or sea waves are the main agent of the shoreline erosion process. Nature of the tidal waves which causes for short term rejuvenation process of the shoreline erosion depends mainly on the extraterrestrial forces (Spencer, E.W.1983). In many cases, human activities concentrated in and around the coastal zone 
influence to accelerate the geomorphic cycles of the shore. Accumulative effects of all these forces determine the intensity of the shorlline erosion cycle (Huggett, 2011). Long term, short term or sudden changes of the geomorphic forces of shore influence to change dynamism of the denudation process of the shore and formation of coastal landforms. In general, short term and sudden changes of the landform formation process of the shoreline create disastrous situations. Number of coastal nation including Sri Lanka are experiencing such malevolence effects at present.

Formation a recession (eroding) or an accretion (forming a depositional shore) shoreline is an outcome of a land mass denudation process of the shore. Shoreline accretion is a result of the shoreline erosion process. As mentioned earlier, the shoreline erosion process is a product of the interplay of the all kind of natural forces that can be seen in the atmosphere, hydrosphere, lithosphere and biosphere. All the forces of the geo-systems act to find their equilibrium within their own system and with other system. All these complex actions and reaction may be surfaced as visible actions or result. Yet, there are other activities such as chemical reaction may not be traced by the naked eyes. However, human activities can accelerate or modify all these natural process which lead to evolve relief features of the coast. It is clear that shoreline erosion factors act together or overlap each other (Hushain, 1989). When considering the views of King (1972) and Hushaian (1989), the factors that regulate the coastal erosion can again be divided into two main groups as short term and long-term factors. Brief accounts of these two category are as follows.

Fig. 02.

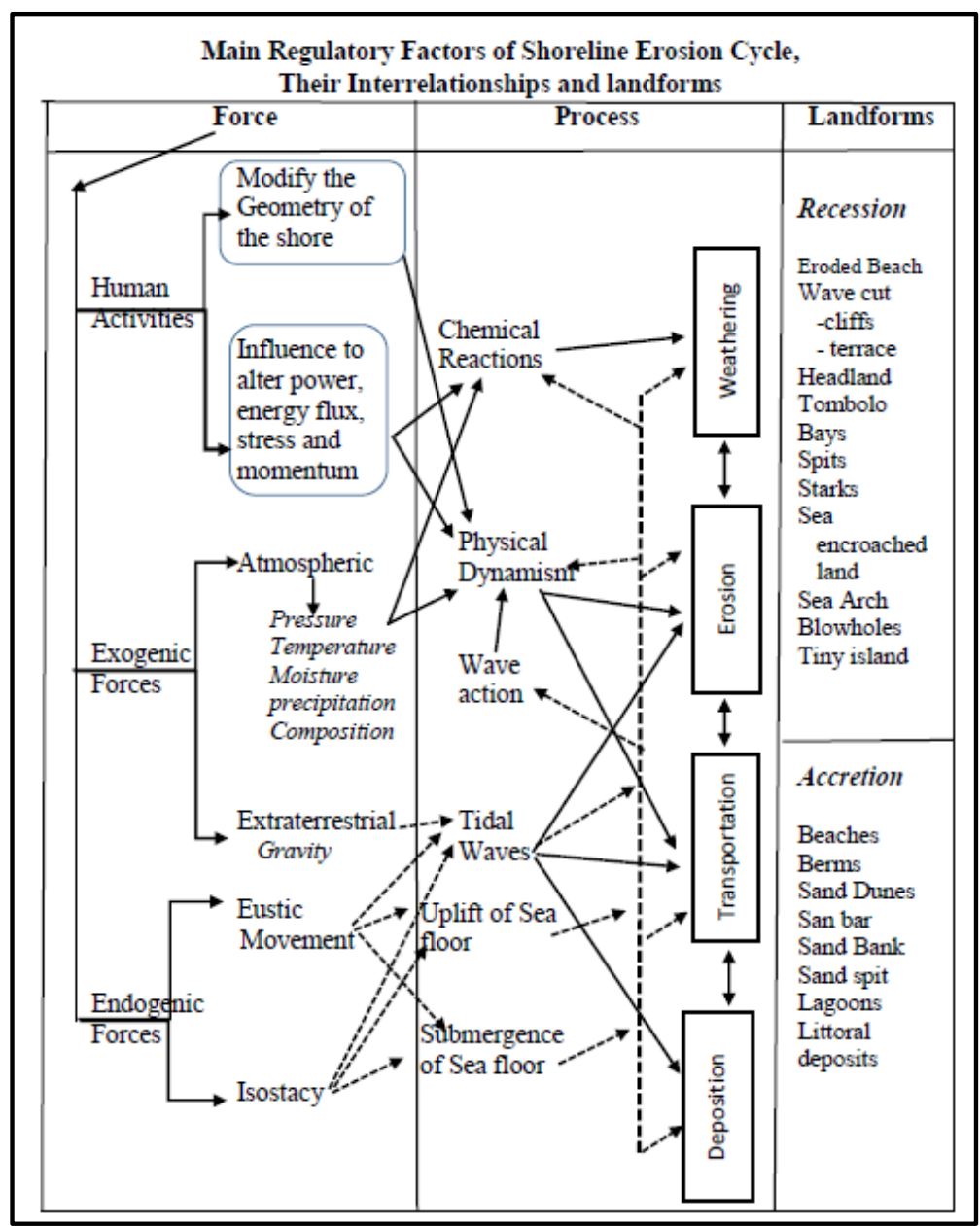




\section{Regulating Factors of Shoreline Erosion: Short Term}

Changes of shoreline can be observed even by second by second, hourly to yearly as the waves of the near shore change relentlessly (Amarasinghe, 2002 and 2004). Changes of wave reaching pattern to shore, seasonal wind patterns and sediment budget of the shore are the main factors that cause to change shoreline erosion process within short period of time (Swan, 1983). Gravitational force of the moon (nature of tides) and morphological characteristics or geometry of the respective shore also effect to change the intensity of shoreline erosion process within the short period of time. Geometry of the shore profile can change providing room to reach powerful waves to hit the shore face when reduction the river sediment supply or removal sand from the beach in large scale. This effect to destroy the existing geometric equilibrium of the shore profile suddenly. Human activities such as removal of near shore vegetation cover and destruction the coral reefs also may further cause to alter the relief features of the coastline (Fig. 03). All these factors have named as "Influential factors" of shoreline erosion process (Swan, 1983).

Concept of shoreline erosion cycle concerns mainly on erosional and depositional process. These two processes cause to produce erosional and depositional landforms of the shore. And also, these landforms are the direct and visible results of this process. It is clear that the processes connecting with erosion and deposition have an undeviating relationship with weathering rocks and transportation the sediments of the coast. Therefore, all these four process: weathering, erosion, transportation and deposition have to be considered as the main parts of the land mass denudation process of the shore. As a whole, this process in generally used synonymously with coastal erosion, sea erosion and wave erosion. At the same time, "shoreline erosion" implies to describe erosional and depositional processes as well as to designate the recession and accretion process and their resulting landforms. This explanation shows that the denudation process of the shoreline is complex and relates with dynamic phenomenon associates with ecosystem that consist with hydrosphere, biosphere, lithosphere and atmosphere (Fig.04).

\section{Regulating factors of Shoreline Erosion: Long Term}

As mentioned above, regulatory factors of shoreline erosion can be divided into three (Fig. 02) as follows;

1. Endogenic processes; eustatic change of sea floor, isostacic equilibrium

2. Exogenic processes; changes of the atmospheric dynamism due to changing atmospheric composition and energy balance.

3. Human activities influenced to change the geometry and geomorphic processes of the shoreline.

Fig. 03 


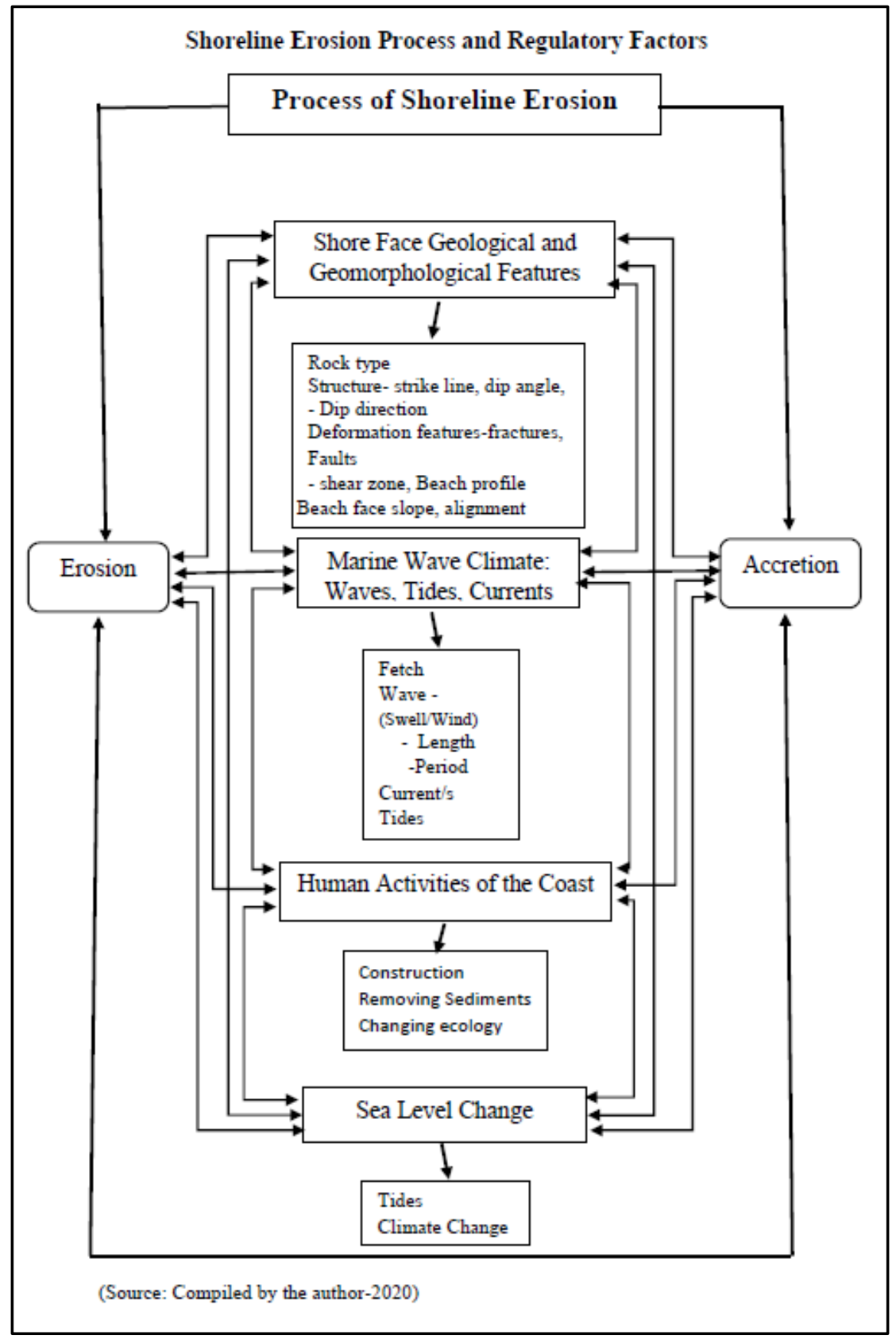

Fig. 04 


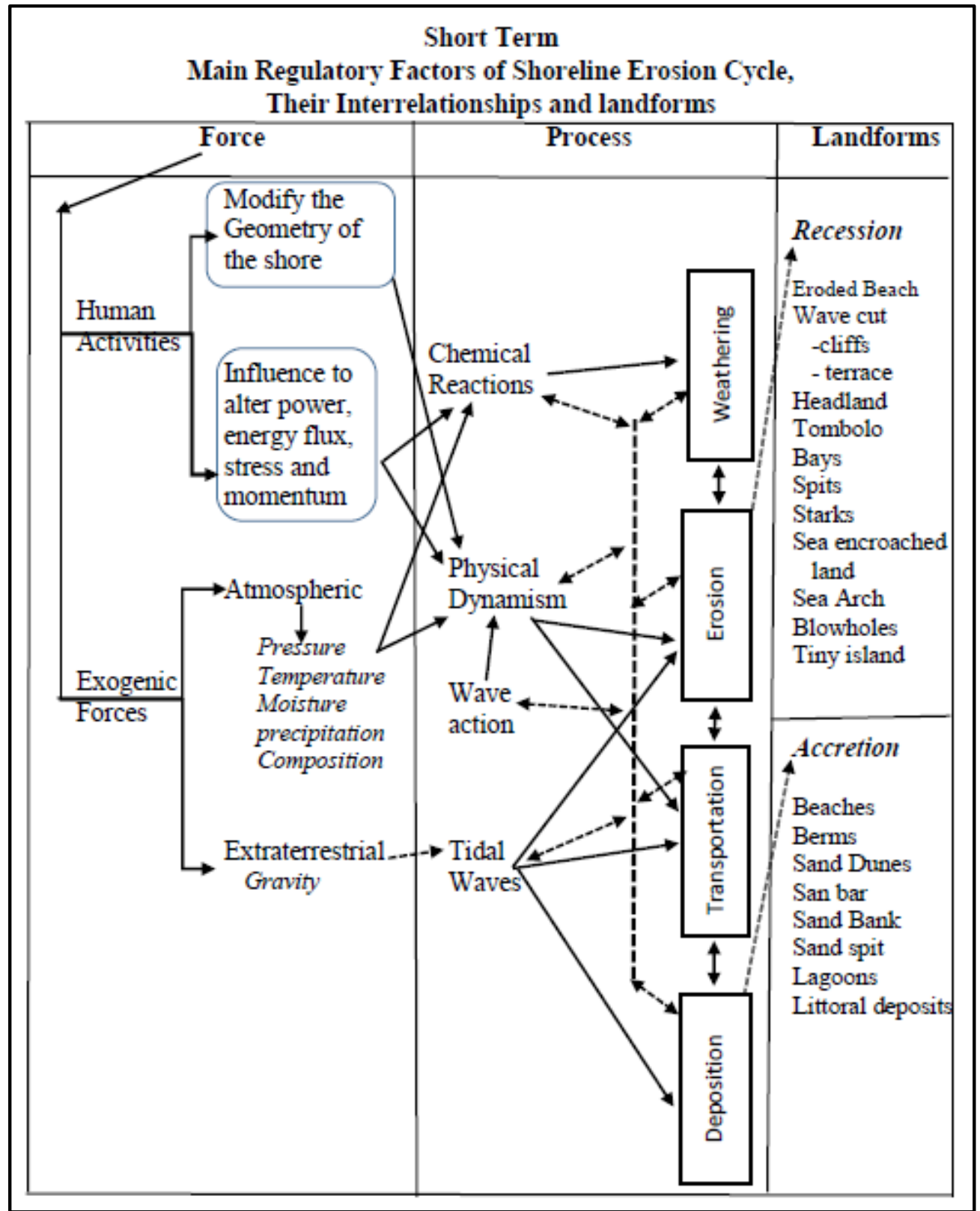

Among these factors, significant change of the Mean Sea Level (MSL) and near shore geometric equilibrium can be categorized as the main two factors that regulate the shoreline erosion process in long run. Rise of the MSL has been recognized as the main impact and the causative factor that led to accelerate shoreline erosion in long term in Sri Lanka (Katupotha, 1992). However, exact evidences of endogenic process that influence to rise sea level is still to be recovered. And also the influence of the changes of the geological activities of the interior of the earth crust is a slow process when comparing with the intensity of current shoreline erosion rate in Sri Lanka. However, real-world situation that measures using instruments have proved that the sea level is rising due to the effects of "climate change" (IPCC,2014). Climate change will certainly be a key responsible factors that regulate the increasing shoreline erosion process in Asian region including Sri Lanka (CCD, 1986, IPCC, 2007, 2013). 
According to the Inter-Governmental Panel of Climate Change (IPCC), coasts are projected to be exposed to increasing risks, including coastal erosion, due to climate change and sea level rise. The effect will be exacerbated by increasing human-induced pressures on coastal areas (very high confidence). By the 2080s, many millions more people than today are projected to experience floods every year due to sea level rise. The numbers affected will be largest in the densely populated and low-lying mega deltas of Asia and small islands are especially vulnerable (very high confidence) (IPCC, 2007 and ,2014)

Increases in sea level are consistent with global warming. Global average sea level rose at an average rate of 1.7 [1.5 to 1.9] $\mathrm{mm}$ per year between 1901 to 2010, 2.0 [1.7 to 2.3]mm per year between 1971 to 2010 and 3.2 [2.8 to 3.6]mm per year between 1993 to 2010 (IPCC: 2013:Climate Change 2013). It is clear that sea level is rising continuously. There are arguments over the exact figure of change. However, sea level rise and the affecting cause for sea level change are admitted by relevant scientists without any doubt at present (Pernetta, 1994). There are many other factors too that can cause to change shoreline in long time span lies ten to hundred years in Sri Lanka. Such factors can be listed as follows,

a. Sea level rise

b. Coastal subsidence due to tectonic events

c. Climatic changes (changing of the storm intensities, shift of the dominant storm directions affecting the approach angle of waves; variation of precipitation and the river regimes and discharges)

d. Increased vegetation cover over the river watersheds due to climatic changes (causing decreased soil erosion and sediment supplied to the coast);

e. Sediment sinks (presence of offshore canyons, movement to great depths at steep slopes, wind transport of sand to inland areas)

f. Changing of river courses and mouths in deltas

Anthropogenic causes of long term coastal erosion are more or less parallel to the natural causes. These are:

a. Decreasing sediment supply by rivers to the coastal physiographic unit (cutting of the sediment transport by damming the rivers, sand and gravel mining along the river beds, decreasing the sediment transport efficiency by lowering water discharges due to increased fresh water use or due to river works such as bank and bed erosion control)

b. Erosion control works and forestation in coastal and riverine watersheds.

c. Decreasing the volume of sand in the physiographic unit (sand mining from the beach and dunes, offshore sand mining).

d. Alteration of the usual pattern of coastal currents and the associated sediment transport along and across the shoreline, due to man-made coastal structures and urban development too close to the shoreline.

e. Anthropogenic changes made to river courses and mouths in deltas.

f. Maintenance dredging of approach channels and estuarine inlets.

g. Land subsidence due to anthropogenic effects.

Construction dam such as protection wall, groins or revetments without understanding the shoreline process, sand mining, coastal structures and urban development close to the shoreline are cited as the factors that have triggered and accelerated coastal erosion (Olsen and Hale, 994, CCD, 1986, Clark, 1996). Other than these activities, construction of reservoirs to store river run off, extensive 
soil erosion conservation methods of watershed and river banks, river sand and gravel mining along the river bed, illegal sand mining from the beach, and construction of coastal structures by property owners have been identified as the main reasons for increasing erosion rates in shorelines in many countries too. It has already identified that the reduction of sediment (sand) of the shoreline due to human activities as one the main factor that increase the shoreline erosion in particularly the South Western coastal zone in Sri Lanka ( CCD,1986; Maddumabandara, 1989, 1991 ; Amarasingeh, 2004).

\section{Results}

Identified factors that increase the shoreline erosion of the study area were classified mainly into two as natural and anthropogenic factors.

Seven main anthropogenic factors that accelerate the coastal erosion of the West coast were identified as follows;

1. Increasing the volume of sand mining: river, beach and offshore

2. Reducing the sediment transport to the sea coast by constructing dams across the rivers

3. Decreasing the sediment transport efficiency by lowering runoff due to increased usage of inland water

4. Shoreline and inland erosion control works and forestation in coastal areas and watersheds.

5. Decreasing volume of sand in South shoreline which supplies sediments to SW shoreline.

6. Alteration of the usual pattern of coastal currents and the associated sediment transport pattern along and across the shoreline by the construction of groins, revetments, other structures and development works close to the shoreline.

7. Changes made to river courses and mouths in deltas by fishing activities to clear the approach channels and estuarine inlets

The natural factors that regulate the coastal erosion in the study area can be divided mainly into two as short and long terms as follows,

- Abrupt change of wave climate -Wind wave, Swell and Currents

- $\quad$ Non return of sediments from off shore

- Problem of coral bleaching

- Decreasing the extent of wetland and mangroves

- Reducing bio-diversity and bio-production of the coastal zone

- Lowering of rainfall in the river catchment areas and decreasing the run off of rivers in the SW region

\section{Conclusion}

It is apparent that many factors that regulate the shoreline erosion process of West coast of Sri Lanka are stable. Fetch, geological features of the shore and endogenic forces around Sri Lankan coast are not change in resent past. Yet, the shoreline erosion is increasing rapidly. That means, except factors mentioned above are responsible to shoreline erosion process of the study area. However, reduction of sediment budget can cause to change shore face profile and geometry of beach. This would effect to increase the slope angle of the shore profile enabling high waves to hit shoreline. Such situation can erode beach and shoreline and increase the power of turbulence current enabling to disturb long shore drift. This would break the sediment supply to adjacent front coast of the long shore drift direction. West coastal sector is a comprised with wide beach. This beach had an equilibrium shoreline erosion 
process up to 2015. Human activities of this coast are not help to trigger the shoreline erosion. Yet the shoreline is eroding significantly from recent past.

When considering the geomorphic process of shoreline erosion in West coast of Sri Lanka, two main factors can be identified as dominant factors that regulate the shoreline erosion as,

1. Constructing hard structures such as groins, revetments and water breakers to protect private and public properties from the process of shoreline erosion along the adjacent shoreline from where beach sediment provide to study area.

2. Reduction of sediment supply into the shore by constructing houses, commercial buildings and other structures along the shore and extensive river and beach sand mining

Other than these two factors, sea level rise that is associated with the process of Climate Change may accelerate the rate of the shoreline erosion in the West coast..

\section{List of references}

Amarasinghe, A.G. 2001, and Shoreline Denudation: Spatial and Temporal Variation of Sea Erosion in South West Coastal Sector in Sri Lanka, Unpublished Thesis submitted to the Faculty of Arts, University of Peradeniya.

Amarasinghe, A.G., (2004), "Shoreline Change in Southwestern Coastal Sector in Sri Lanka: Dominant Factors Controlling the Shoreline erosion Rate", Postgraduate Research Symposium -2004, Faculty of Arts, University of Peradeniya.

Amarasinghe, A.G., (2020) "Intensity of Coastal Erosion in Sri Lanka: The Case of South Western Coastal Sector", American Journal of Multidisciplinary Research \& Development (AJMRD), Volume 2, Issue 11 (November- 2020), PP 01-07, www.ajmrd.com.

Bakker, Paul J. J. 2018, Future Coastline Recession and Beach Loss in Sri Lanka- Master of Science (MSc) graduation thesis, University of Twente. Available at

CCCRMD, 2018, Coastal Zone Management Plans. Coast Conservation and Coastal Resources Management Department (CCCRMD), New Secretariat, Maligawatta, Colombo 10. Available at, http://coastal.gov.lk/images/ pdf/acts/ czcrmp_2018_gazette_2072_58_e.pdf

CCD,1987, Coastal Zone management Plan (Revised). Coast Conservation Department, New Secretariat, Maligawatta, Colombo 10. CCD. (1986) Master Plan Coast Erosion Management. Vol. I,II, Coast Conservation Department (CCD) \& Danida- Danish Hydraulic Institute, New Secretariat, Maligawatta, Colombo 10.

CCD. (1997) Coastal Zone Management Plan. Coast Conservation Department (CCD), New Secretariat, Maligawatta, Colombo 10.

Clark, John R. 1996, Coastal Management Hand Book, Lewis Publishers, Boca Raton, Florida, 33431.

Cooray, P.G. 1983, An Introduction to Geology in Sri Lanka, National Museum in Sri Lanka, Colombo, Sri Lanka.

Pernetta, John, 1994, "Facing up to sea rise", The People and the Planet: Life on the Margin- IPPF, UNFPA, IUCN, Planet 21, 60Twisden Road, London, NW5 IDN, UK.pp-10-11.

Haggett, Peter, 1979, Geography: A modern Synthesis $3^{\text {rd }}$ ed., Harper and Row Publishers, New York, USA.

Hinrichsen, Don, 1994, "Coast Under Pressure", The People and the Planet: Life on the Margin- IPPF, UNFPA, IUCN, Planet 21, 60Twisden Road, London, NW5 IDN, UK. Pp. 6-9.

Huggett, Richard John, 2011, Fundamentals of Geomorphology $3^{\text {rd }}$ ed. (An eBook). Routledge, 2 Park Square, Milton Park, Abingdon, Oxon, OX14 4RN, London, UK. www.eBookstore.tandf.co.uk

Hushain, Hazian. 1989, “ Preliminary Evaluation of the photogrammetric Remote Sensing Approch in Monitoring Shoreline Erosion", Proceedings of the $10^{\text {th }}$ Asian Conference on Remote Sensing, Nov. 23 -29, 1989, Kuala Lumpur, Malaysia, pp. F/5/1-10.

IPCC , 2007, Summary for policymakers. In: Climate Change 2007: The Physical Science Basis (ed. by S. Solomon, D. Qin, M. Manning, Z. Chen, M. Marquis, K. B. Averyt, M. Tignor \& H. L. Miller). Cambridge University Press, UK.

IPCC, 2013: Climate Change 2013: The Physical Science Basis, Contribution of Working Group I to the Fifth Assessment Report of the Intergovernmental Panel on Climate Change [Stocker, T.F., D.Qin, G.-K. Plattner, M, Tignor, S.K. Allen, J.Boschung,A. Nauels, Y.Xia, V. Bex and P.M. Midgley (eds.)]. Cambridge University Ores, Cambridge, United Kingdom and New York, NY, USA, 1535pp.

IPPC, 2014: Climate Change 2014: Impacts, Adaptation, and Vulnerability. Part A: Global and Sectoral Aspects, Contribution of Working Group II to the Contribution of Working Group II to the Fifth Assessment Report of the Intergovernmental Panel on Climate Change [Field, C.B., Barros, V.R., D.J. Dokken, K.J. Mach, M.D. Mastrandrea, T.E. Bilir, M. 
Chatterjee, K.L. Ebi, Y.O. Estrada, R.C. Genova, B. Girma, E.S. Kissel, A.N. Levy, S. MacCracken, P.R. Mastrendrea, and L.L. White (eds.)]. Cambridge University Ores, Cambridge, United Kingdom and New York, NY, USA, 1132pp.

IPPC, 2014: Climate Change 2014: Impacts, Adaptation, and Vulnerability. Part B: Regional Aspects, Contribution of Working Group II to the Contribution of Working Group I to the Fifth Assessment Report of the Intergovernmental Panel on Climate Change [Barros, V.R., C.B. Field,D.J. Dokken, M.D. Mastrandrea, K.J. Mach, T.E. Bilir, M. Chatterjee, K.L. Ebi, Y.O. Estrada, R.C. Genova, B. Girma, E.S. Kissel, A.N. Levy, S. MacCracken, P.R. Mastrendrea, and L.L. White (eds.)]. Cambridge University Ores, Cambridge, United Kingdom and New York, NY, USA, 688pp.

Katupotha, Jinadasa, 1992, “New Evidence of Holocene Sea Level Change in Sri Lanka”. Journal of the Geological Socity of Sri Lanka. Vol. 4, 1992, pp 39- 44.

King, Cuchlaine, A.M. 1972, Beaches and Coasts, Edward Arnold (Pub.). Ltd, London.

Lakmali, E.N., et all, 2016, "Long Term Coastal Erosion and Shoreline Positions of Sri Lanka” Proceedings of ERE 2016, https://www.researchgate.net/ publication/307301862

Leopold, Luna B., Wolman, M Gordon. and Miller, John P. 1964, Fluvial Processes in Geomorphology, W.H. Freeman and Company, San Francisco, USA.

Maddumabandara, C. M. 1989. Coastal Changes of Crow Island and its environs. Coast Conservation Department(CCD), New Secretariat, Mligawaththa, Colombo 10,Sri Lanka.

Maddumabandara, C.M. 1991, "Case Studies in Shoreline Trends in South West", Proceedings of the Seminar on Coastal Erosion in Sri Lanka: Colombo 9 -11 Feb. 1991, CCd/GTZ Project, New Secretariat, Maligawatta, Colombo 10.

Olsen, Stephen and Hale, Lynne Zeitlin , 1994, "Coasts: the Ethical dimention", The People and the Planet: Life on the Margin- IPPF, UNFPA, IUCN, Planet 21, 60- Twisden Road, London, NW5 IDN, UK.

Perera, M.D.N.D. et all, 2017, "Risk of Seawater Intrusion on Coastal Community of Bentota River Basin Sri Lanka", Procedia Engineering 212 (2018) 699-706, ELSERVER.Com/ Locate / Procedia., Available online at www.sciencedirect.com.

Spencer, Edgar W.1983, Physical Geology, Addison-Wesley Publishing Company, Inc. USA.

Swan, Bernard, 1965, "Coast Erosion Principles and a classification of South West Ceylon Beaches on the basis their erosion stability". The Ceylon Geographer. Vol. 19. No. 1- 4, Jan. to Dec. 1965. PP 1 -16.

Swan, Bernard, 1983, An Introduction to the Coastal Geomorphology of Sri Lanka. National Museum of Sri Lanka, Colombo, Sri Lanka. 